DiH Jurnal Ilmu Hukum

Volume 14 Nomor 27

Februari 2018

Jemikan

\title{
KAJIAN YURIDIS TERHADAP PELAKSANAAN BPJS KETENAGAKERJAAN \\ DI LINGKUNGAN YAYASAN PERGURUAN 17 AGUSTUS 1945 SURABAYA ${ }^{1}$ Jemikan
}

Fakultas Hukum

Universitas Ma'arif Hasyim Latif Sidoarjo

\begin{abstract}
Abstrak
Pembangunan Nasional yang selama ini merupakan Pengalaman Pancasila, dilaksanakan dalam rangka pembangunan manusia seutuhnya, adil makmur dan damai baik material maupun sepiritual. Semakin meningkat peran pembangunan dapat mengakibatkan semakin tingginya resiko yang mengancam keselamatan, kesehatan dan kesejahteraan tenaga kerja. Dengan demikian perlu adanya upaya perlindungan terhadap tenaga kerja. Maka dari itu Badan Penyelenggara Jaminan Sosial bagi tenaga kerja sebagai perwujudan aspirasi perlindungan ketenagakerjaan yang mempunyai dampak positif terhadap peningkatan disiplin kerja. Sanksi hukum dalam pelaksanaan dan penerapan jaminan sosial bagi tenaga kerja sangat diperlukan, tidak hanya di dalam lingkungan perusahaan yang berbadan hukum seprti perseroan terbatas, yayasan, koperasi akan tetapi juga orang perorangan juga pemberi kerja sekalipun wajib menjadi anggota. Program Jaminan Sosial Tenaga kerja awal mulanya merupakan suatu perwujudan dari Peraturan Pemerintah Nomor 33 Tahun 1997 yang dituangkan dalam Pasal 3, yang menyatakan bahwa Perusahaan wajib menyelenggarakan program Asuransi Tenaga kerja baik dengan mempertanggungkan tenaga kerjanya yang bekerja dalam suatu ikatan kerja dengan perusahaan dalam program asuransi kecelakaan kerja dan asuransi kematian, maupun dengan memenuhi kewajibannya dalam program tabungan hari tua kepada badan penyelenggara. Jaminan Sosial Bagi Tenaga kerja merupakan suatu perlindungan bagi tenaga kerja dalam bentuk berupa uang sebagai pengganti sebagian dari penghasilan yang hilang atau berkurang sebagai akibat suatu peristiwa atau keadaan yang di alami oleh tenagakerja. Hal ini bisa berupa kecelakaan, sakit, hamil, bersalin, hari tua dan meninggal dunia. Dengan uraian ini, penulis ingin mengamati penerapan sanksi penyelenggaraan program Jaminan Sosial BPJS Ketenagakerjaan yang dilaksanakan oleh Yayasan Perguruan 17 Agustus 1945 Surabaya, yang pelaksanaan program ini dimulai sejak tahun 2004 yang masih dikelola Jamsostek, setelah keluar dari Asuransi Jiwasraya. Sebelum menjadi BPJS Ketenagakerjaan dan BPJS Kesehatan, program Jamsostek kala itu ada 4 program yang terdiri dari jaminan kecelakaan kerja (JKK), jaminan kematian (JKM), jaminan hari tua (JHT) dan jaminan kesehatan [JPK] sedangkan untuk program pensiun BPJS Ketenagakerjaan baru berlaku mulai per 1 Juli 2015. Sedangkan untuk jaminan pemeliharaan kesehatan (JPK) yang saat ini dikelola oleh BPJS Kesehatan.
\end{abstract}

Kata kunci: BPJS, ketenagakerjaan, yayasan

\section{A. Pendahuluan}

\section{Latar Belakang Masalah}

Dalam rangka melaksanakan perlindungan segenap bangsa dan seluruh tumpah darah Indonesia dan memajukan kesejahteraan umum sebagaimana yang telah diamanatkan dalam pembukaan Undang-Undang Dasar Negara pemerintah melaksanakan pembangunan disegala bidang terutama bidang yang berkaitan dengan hak Pekerja dan Jaminan Sosial. Peningkatan perlindungan tenaga kerja adalah merupakan wahana yang harus diciptakan bagi setiap insan khususnya tenaga kerja baik yang melakukan pekerjaan dalam hubungan kerja langsung maupun tidak langsung, karena tenaga kerja dimanapun baik di sektor jasa maupun sektor industri wajib mendapatkan perlindungan dari tempatnya bekerja. Dari uraian-uraian ini maka jaminan sosial tenaga kerja yang sekarang dikelola Badan Hukum Penyelenggara Jaminan Sosial (BPJS) akan berperan aktif sebagai perwujudan aspirasi

${ }^{1}$ DOI 10.5281 /zenodo.1188372. 
perlindungan ketenaga kerjaan yang mempunyai dampak positif terhadap usaha-usaha peningkatan disiplin kerja dan peningkatan produktivitas tenaga kerja. Pemberi Kerja termasuk pengusaha, Pengurus Yayasan/ Koperasi dan Usaha mandiri sebagaimana diatur dalam Pasal 15 Undang-Undang Nomor 24 Tahun 2011 tentang BPJS adalah wajib mendaftarkan dirinya dan pekerjanya di BPJS, di samping itu pemberi kerja wajib memperhatikan peningkatan kesejahteran tenaga kerja berdasarkan kemampuan dan kemajuan yang dicapai permberi kerja.

Sebelum berlakunya Undang-Undang Nomor 13 Tahun 2003 tentang Ketenagakerjaan di dalam Pasal 1 angka 1 juga mengatur tentang Jaminan Sosial. Jaminan Sosial Tenaga kerja ini awal mulanya merupakan suatu perwujudan dari Peraturan Pemerintah Nomor 33 Tahun 1997 yang dituangkan dalam Pasal 3, yang menyatakan bahwa "Perusahaan wajib menyelenggarakan program Asuransi Tenaga kerja baik dengan mempertanggungkan tenaga kerjanya yang bekerja dalam suatu ikatan kerja dengan perusahaan dalam program asuransi kecelakaan kerja dan asuransi kematian, maupun dengan memenuhi kewajibannya dalam program tabungan hari tua kepada badan penyelenggara'. ${ }^{2}$

Hal tersebut di atas adalah salah satu sarana yang merupakan perwujudan dalam meningkatkan dan menciptakan ketenangan, kemantapan bekerja pada perusahaan atau pemberi kerja. Sedangkan BPJS memberikan kewajiban kepada pemberi kerja untuk mempertanggungkan dirinya dan pekerjanya dengan cara mendaftarkan ke BPJS baik BPJS Ketenagakerjaan maupun BPJS Kesehatan terhadap risiko kecelakaan kerja, sakit cacat akibat kerja, kematian.

Peraturan lebih lanjut tentang jaminan sosial tenaga kerja ini dapat dilihat dalam:

a. Undang-Undang Republik Indonesia Nomor 40 Tahun 2004 tentang Sistem Jaminan Sosial.

b. Undang-Undang Republik Indonesia Nomor 24 Tahun 2011 tentang Badan Penyelenggara Jaminan Sosial.

c. Peraturan Pemerintah Republik Indonesia Nomor 14 tahun 1993 tentang Penyelenggaran Program Jaminan Sosial Tenaga Kerja dan perubahannya yang ketujuh dengan Peraturan Pemerintah Nomor 84 Tahun 2013.

d. Peraturan Pemerintah Republik Indonesia Nomor 85 Tahun 2013 tentang Tata Cara Hubungan Antar Lembaga BPJS.

e. Peraturan Pemerintah Republik Indonesia Nomor 86 Tahun 2013 tentang Tata Cara Pengenaan Sanksi Administratif Kepada Pemberi Kerja selain Penyelenggara Negara dan setiap orang, selain Pemberi Kerja, Pekerja \& Penerima Bantuan Iuran dalam Penyelenggara Jaminan Sosial.

f. Peraturan Pemerintah Republik Indonesia Nomor 109 Tahun 2013 tentang Penahapan Kepesertaan Program Jaminan Sial.

g. Peraturan Pemerintah Republik Indonesia Nomor 44 Tahun 2015 tentang Penyelenggaraan Program Jaminan Kecelakaan Kerja dan Jaminan Kematian.

h. Peraturan Pemerintah Republik Indonesia Nomor 45 Tahun 2015 tentang Penyelenggaraan Program Jaminan Pensiun.

\footnotetext{
2 Imam Soepomo, Hukum Perburuhan, Djambatan, Jakarta, 1992, hlm. 180.
} 
DiH Jurnal Ilmu Hukum

Volume 14 Nomor 27

Februari 2018

Jemikan

i. Peraturan Pemerintah Republik Indonesia Nomor 46 Tahun 2015 tentang Penyelenggaraan Program Jaminan Hari Tua.

\section{Rumusan Masalah}

Berdasarkan uraian di atas, masalah-masalah yang dibahas dalam hal ini adalah:

a. Apakah Undang-Undang Republik Indonesia Nomor 24 Tahun 2011 tentang Jaminan Sosial memberikan perlindungan terhadap kesejahteraan bagi pegawai yayasan

b. Sanksi hukum terhadap pelaksanaan BPJS Ketenagakerjaan di lingkungan Yayasan Perguruan 17 Agustus 1945 Surabaya?

\section{Metode Penelitian}

Metode yang digunakan dalam penelitian ini adalah yuridis normatif artinya penelitian dilakukan terhadap suatu peraturan perundang-undangan yang berkaitan dengan jaminan sosial tenaga kerja, dengan pendekatan-pendekatan perundang-undangan dan pendekatan konsep.

\section{B. Pembahasan}

Hubungan kerja antara karyawan dangan Pengurus Yayasan Perguruan 17 Agustus 1945 Surabaya diharapkan dapat menciptakan kerja sama yang serasi dengan landasan semangat Pancasila dan Undang-undang Dasar 1945. Dalam hubungan kerja masing-masing pihak antara karyawan dangan pengurus yayasan tertuang dalam Bab III Pasal 8 sampai dengan Pasal 11 Peraturan Karyawan Yayasan Perguruan 17 Agustus 1945 Surabaya.

a. Kewajiban Karyawan adalah sebagai berikut:

- bekerja dengan tepat waktu sesuai dengan jam kerja yang telah ditetapkan;

- mentaati perintah dan instruksi atasan langsung, melakukan presensi dan tidak meninggalkan tempat bekerja sebelum waktunya tanpa ijin dst.

b. Hak Karyawan

- mendapatkan upah/gaji yang layak sesuai peraturan peraturan perundangan yang berlaku dan ketentuan yayasan, sebagai imbalan atas kontribusi tenaga, pikiran dan waktu waktu dalam menjalankan tugas pekerjaannya;

- mendapatkan tunjangan dan fasilitas-fasilitas lainnya sesuai peraturan yang berlaku;

c. Sedangkan Kewajiban Pengurus Yayasan adalah sebagai berikut:

- memberikan upah/ gaji, tunjangan-tunjangan sesuai dengan ketentuan yang berlaku;

- menjamin serta meningkatkan keselamatan dan kesehatan kerja karyawan;

- menjamin peningkatan kesejahteraan karyawan sesuai dengan ketentuan yang berlaku;

- menjaga dan membangun keharmonisan dengan karyawan dan saling menghargai agar tercipta iklim kerja yang baik guna memacu perkembangan dan kemajuan lembaga;

d. Hak Yayasan

- menerima,mengangkat, menempatkan dan memberhentikan karyawan;

- mewajibkan karyawan memberikan kontribusi dan prestasi kerja sesuai dengan standar;

- menetapkan dan mengubah aturan atau tata tertib kerja; 
- mengadakan promosi, mutasi dan pemutusan hubungan kerja sesuai dengan ketentuan yang berlaku.

Sebelum lahirnya undang-undang tentang BPJS untuk pertama kali masalah perlindungan tenaga kerja ini telah diatur dalam bab IV, Pasal 9 Undang-undang Nomor 14 Tahun 1969 tentang pokok-pokok tenaga kerja. Dan sebagai tindak lanjut juga diatur dalam pasal 27 Undang-undang Nomor 3 tahun 1992 menyebutkan bahwa pengendalian terhadap penyelenggaraan program jaminan sosial tenaga kerja oleh badan penyelenggara, sebagaimana dimaksud dalam undang-undang Nomor 24 tahun 2011 dilakukan oleh Badan Penyelenggara Jaminan Sosial di bawah Presiden. Sedangkan dalam pengawasan mengikutsertakan unsur Pemerintah yang membawai ketenagakerjaan, pengusaha dan unsur pekerja, dalam wadah yang menjalankan fungsi Undang-undang yang berlaku. Pengawasan ketenagakerjaan diarahkan kepada usaha preventif dan edukatif. Namun demikian tindakan represif baik yang yustisial maupun non-yustisial yang dilaksanakan secara bertahap.

- Aparat pengawasan diharapkan lebih peka dan cepat bertindak terhadap masalahmasalah yang timbul dan mungkin akan timbul dilapangan, sehingga masalahnya tidak meluas.

- Aparat pengawasan dalam melaksanakan tugas dan fungsi pengawasan diharuskan turun langsung ke lapangan untuk melihat permasalahannya secara langsung, sehingga dapat dijamin objektivitasnya.

- Pemanfaatan aparat pengawas secara optimal sehingga dapat menjangkau objek pengawasan seluas mungkin khususnya pada sector-sektor yang dianggap rawan dan strategis.

Pengawasan memang penting untuk mengetahui dari dekat pelaksanaan kewajiban yang diemban oleh pengurus yayasan. Turunnya pengawas kelapangan berarti akan mengetahui secara obektif permasalahan yang terjadi sehingga pemecahan hukumnya dapat dilakukan secara objektif. Masalah pengawasan ketenaga kerjaan pada awalnya diatur dalam Undangundang Nomor 13 tahun 2003 tentang Ketenagakerjaan diatur dalam Pasal 176 s/d Pasal 181. Hal ini diperlukan untuk memberi kenyamanan, ketenangan dan kedamaian pekerja maupun pengusaha. Sedangkan Pengawasan Ketenaga Kerjaan bertujuan

- Mengawasi berlakunya Undang-undang dan Peraturan-peraturan khususnya.

- Mengumpulkan bahan-bahan keterangan mengenai hubungan kerja dan keadaan ketenaga kerjaan dalam arti seluas-luasnya, guna memuat undang-undang dan peraturan lainnya.

- Menjalankan pekerjaan lainnya yang diserahkan kepadanya dengan undang-undang dan peraturan lainnya.

Pengawasan terhadap perusahaan oleh pemerintah dalam program Jaminan Sosial merupakan hal yang penting untuk menegakkan hukum, yang dilakukan melalui pemantauan terhadap pelaksanaan undang-undang Nomor 24 Tahun 2011 tentang BPJS, sehingga undang-undang tersebut berjalan lebih efektif. Salah satu faktor yang sangat menentukan efektifitas penegakan hukum adalah sistem sanksi. ${ }^{3}$

Penegakan hukum dalam ranah hukum pidana berkaitan langsung dengan sanksi pidananya, sedangkan penegakan hukum dalam ranah hukum perdata berkaitan erat

${ }^{3}$ Sukarton Marmosujono, Penegakan Hukum di Negara Pancasila, Pustaka Kartini, Jakarta, 1980, hlm. 20. 
DiH Jurnal Ilmu Hukum

Volume 14 Nomor 27

Februari 2018

Jemikan

dengan ganti kerugian. Sanksi pidana yang berkaitan dengan perusahaan biasanya meliputi hukuman penjara, hukuman denda dan hukuman kurungan. Sedangkan sanksi perdata yang berkaitan dengan perusahaan adalah ganti rugi atas kerugian atau kerusakan yang telah ditimbulkan. Selain sanksi-sanksi tersebut, penegakan hukum yang dilakukan oleh pemerintahn dalam rangka perlindungan jaminan sosial tenaga kerja berhubungan dengan pemberian sanksi administratif yaitu tidak mendapatkan layanan publik. Sedangkan mengenai sanksi administrasi diatur tersendiri melalui Peraturan Pemerintah Nomor 86 Tahun 2013 tentang Tata Cara Pengenaan Sanksi Administrasi Kepada Pemberi Kerja selain Penyelenggara Negara, Pasal 59 PP Nomor 44 Tahun 2015, tentang JKK dan JKM, Pasal 34 PP Nomor 45 Tahun 2015 tentang Program Jaminan Pensiun dan Pasal 33 PP Nomor 46 Tahun 2015 tentang JHT, semua itu mengatur tentang pengenaan sanksi administratif bagi pemberi kerja, tenaga kerja dan badan penyelenggara yang memenuhi ketentuan undangundang ini. Sedangkan didalam UU No. 40 Tahun 2004 tentang Sistem Jaminan Sosial maupun UU No. 24 Tahun 2011 tentang BPJS tidak mengatur tentang sanksi. Untuk membahas lebih lanjut tindakan penegakan hukum oleh Pemerintah dalam rangka perlindungan jaminan sosial tenaga kerja dalam tulisan ini akan diuraikan macam-macam tindakan penegakan hukum administratif.

\section{Penegakan Hukum Dan Pengawasan Pelaksanaan Jaminan Sosial Tenaga Kerja}

Penegasan dilakukan agar undang-undang ini dalam pelaksanaannya di masyarakat dapat dipatuhi dan ditaati tanpa terjadi gejolak sosial. Kesadaran hukum merupakan salah satu komponen tegaknya hukum, disamping produk hukum dan para penegak hukumnya. Kesedaran hukum sangat berpengaruh terhadap efektifitas hukum. Faktor-faktor yang mempengaruhi penegakan hukum adalah: 4

1. Faktor hukumnya sendiri, jadi pruduk hukum yang dibuat tidak bisa menjangkau permasalahan yang ada;

2. Faktor penegak hukum yakni pihak-pihak atau aparat yang bertugas, maupun penerapan hukum yang tebang pilih;

3. Faktor sarana dan fasilitas yang mendukungnya;

4. Faktor masyarakat, yakni lingkungan dimana hukum itu berlaku;

5. Faktor kebudayaan, yakni sebagai hasil karya cipta dan rasa yang di dasari pada karsa manusia di dalam pergaulan hidup.

Dalam kenyataannya kelima faktor tersebut berkait satu sama lain, namun yang dibahas dibatasi hanya yang bersifat yuridis saja. Dua Faktor yang mempunyai sifat yuridis itu adalah faktor produk hukumnya dan faktor penegak hukumnya. Dalam kaitan dengan faktor hukumnya menurut Abdoel Gani bahwa "Setiap Peraturan hukum yang diperlakukan dan atau dikenakan pada para anggota masyarakat seyogyanya peraturan tersebut telah memenuhi beberapa syarat. Persyaratan tersebut diperlukan karena setiap anggota masyarakat ingin mendapatkan jaminan bahwa peraturan hukum itu akan ditaati ${ }^{4}$ Soerjono Soekanto, Faktor-Faktor Yang Mempengaruhi Penegakan Hukum, Raja Grafindo, Jakarta, 2013
hlm. 3-4. 
oleh masyarakat, sehingga tidak banyak menimbulkan kesulitan dalam penegakannya". ${ }^{5}$ Dalam setiap peraturan hukum, persyaratan formil dan materiil harus dipenuhi agar tercipta peraturan yang idial dalam rangka penegakan hukum. Persyaratan formil, menyangkut cara, kekuasaan dan wewenang pembuatan peraturan ditambah dengan pemenuhan syarat mengenai tata urutan. Apabila persyaratan ini tidak diperhatikan maka peraturan atau produk hukum yang dihasilkan justru menjadi tidak fungsional artinya tujuannya tidak akan tercapai. Persyaratan materiil meliputi: 6

1. Kelanggengan aturan hukum;

2. Jangkauan pikiran jauh kedepan, sekaligus berarti mencegah lekas usang peraturan hukum;

3. Memperpendek jarak waktu antara pengaturan dan fakta;

4. Peminjaman hak dan kepentingan warga masyarakat secara proporsional;

5. Pemakaian permasyalahan yang akan diatur secara menyeluruh;

6. Mempertimbangkan tata urutan peraturan perundang-undangan;

7. Mencegah timbulnya kemungkinan poli-interpretabilitas terhadap peraturan hukum pertimbangan-pertimbangan tersebut sewajarnya tercantum isi dan merupakan substansi peraturan hukum.

8. Penguasaan bahasa.

Menurut C.G. Howard dan R.S. Mumner, syarat-syarat yang harus dipenuhi agar ketentuan hukum menjadi efektif antara lain:

1. Undang-undang harus dirancang dengan baik;

2. Undang-undang itu seyogyanya bersifat melarang dan bukannya mengatur;

3. Sanksi yang dicantumkan harus sepadan dengan sifat undang-undang yang dilanggar;

4. Berat sanksi yang diancam kepada si pelanggar tidak boleh keterlaluan;

5. Kemungkinan untuk mengamati dan menyelidiki atau penyidik perbuatan yang melanggar undang-undang itu harus ada;

6. Hukum yang mengandung larangan-larangan moral akan lebih efektif dari pada hukum yang tidak selaras dengan kaidah moral atau yang netral;

7. Mereka yang bekerja sebagai pelaksana-pelaksana hukum harus menunaikan tugasnya dengan baik. ${ }^{7}$

Penegakan hukum bagi jaminan sosial tenaga kerja tidak akan terlepas dengan faktor-faktor yang mempengaruhi penegakan hukum termasuk didalamnya persyaratan formil dan persyaratan materiil yang harus dipenuhi. Dalam Undang-Undang Nomor 3 Tahun 1992 Pasal 29 ditetapkan bahwa hukum kurungan selama-lamanya enam bulan atau denda setinggi-tingginya Rp. 50.000.000.-00 (lima puluh juta rupiah) bagi para pelanggar ketentuan jaminan sosial. Akan tetapi dengan lahirnya Undang-Undang Nomor 24 Tahun 2011 tentang BPJS sanksi dipidana kurungan dan pencabutan ijin usaha tidak berlaku lagi.

Sekalipun sanksinya tidak sekeras Undang-Undang Nomor 3 Tahun 1992, akan tetapi semua pemberi kerja yang mempekerjakan karyawan seperti yang di tentukan oleh

\footnotetext{
5 Abdul Gani, Penegakan Hukum, Beberapa Masalahnya, Diskusi Mengenai Penerapan Hukum Di Lingkungan Kota Surabaya, Fakultas Hukum Unair, Surabaya, 1981, hlm. 4.

${ }^{6}$ Ibid.

7 Soetandyo Wignyosubroto, Faktor-Faktor Yang Mempengaruhi Ke Efektifan Hukum Yang Melaksanakan Fungsinya Sebagai Sarana Kontrol Sosial. Terjemahan dari CG. Howard dan Mumner Law. He Nature and Limit, New Jersey, Prentice. Hall. 1965, hlm. 46-47.
} 
DiH Jurnal Ilmu Hukum

Volume 14 Nomor 27

Februari 2018

Jemikan

undang-undang tersebut wajib mendaftarkannya di Program BPJS. Hal ini diatur dalam Pasal 3 ayat (1) Peraturan Pemerintah Nomor 86 Tahun 2013. Ketentuan ini menyatakan “Pemberi kerja selain Penyelenggara Negara Wajib : mendaftarkan dirinya dan pekerjanya sebagai peserta BPJS secara bertahab sesuai dengan program jaminan sosial yang diikutinya dan memberikan data dirinya dan pekerjanya berikut anggota keluarganya kepada BPJS secara lengkap dan benar, sebagaimana dimaksud dalam ayat (1)". Peraturan Karyawan yayasan perguruan 17 Agustus 1945 Surabaya. Sedangkan Penyebab beberapa perusahaan atau pengurus yayasan tidak mengikuti program ini adalah: ${ }^{8}$

a. Kesadaran hukum yang kurang

Kesadaran hukum merupakan hal yang sangat penting, karena meskipun peraturan perundang-undangan dan penegak hukumnya baik tetapi tanpa dibarengi dengan kesadaran hukum masyarakat, dapat dipastikan terjadi pelanggaran. Dalam kaitan ini kesadaran hukum para pengusaha sangat diperlukan agar tidak melanggar ketentuan jaminan sosial tenaga kerja.

b. Lebih mengutamakan kepentingan uang (bisnis)

Tujuan utama pengusaha adalah mendapatkan laba (profit oriented). Karenanya tidak jarang ada yang berusaha menghindari kewajiban mengikuti program jaminan sosial tenaga kerja. Keikut sertaan dalam program tadi dianggap sebagai suatu pemborosan belaka, karena dinilai tidak mendatangkan keuntungan.

c. Kurang memperhatikan nasib tenaga kerja .

Konsekuensi logis dari profit oriented tersebut menyebabkan pihak pengusaha kurang memperhatikan nasib karyawan, seperti jaminan sosial. Padahal jaminan sosial tenaga kerja tadi dimaksudkan untuk meningkatkan kualitas mutu pelayanan yang dilakukan oleh karyawan yang terdiri dari dosen, guru dan tenaga kependidikan terhadap Masyarakat demi kelancaran proses belajar mengajar Yayasan Perguruan 17 Agustus 1945 Surabaya.

d. Upah tidak dilapurkan secara benar

e. Meskipun ketentuan gaji/upah minimum (UMK) telah ditetapkan pemerintah namun dalam praktek pengusaha selalu berusaha tidak memenuhi syarat-syarat kepersertaan program Jaminan Sosial atau BPJS. Dampak upah menyebabkan perusahaan tidak ingin mengikutsertakan karyawannya kedalam semua program. Keikutsertaan dalam program BPJS merupakan beban yang harus dihindari. Keikut sertaan karyawan Yayasan Perguruan 17 Agustus 1945 Surabaya, dalam program BPJS mengharuskan Yayasan membayar premi ke Badan Penyelenggara Jaminan Sosial. Ha ini acap kali oleh beberapa pemberi Kerja dianggap sebagai beban tambahan yang harus dihindari. Untuk menghindari semakin menurunnya kepersertaan, diperlukan pengawasan. Perlu diawasi oleh instansi pengawasan yang professional. Pengawasan ini pelaksanaannya tercantum dalam pasal 13 sampai dengan pasal 15 Peraturan Pemerintah Nomor 86 Tahun 2013, bahkan didalam ayat 3 dari pasal 13 ini menyebutkan "Pengawasan dan pemeriksaan sebagaimana dimaksud pada ayat 1 dilaksanakan oleh BPJS".

8 Arbi Harun, Kepala Kantor Cabang BPJS Ketenaakerjaan Rungkut dalam dalam wawancaranya pada Hari Selasa, 26 Juli 2016. 


\section{Praktek Penegakan Hukum Jaminan Sosial Tenaga Kerja}

Kenyataannya penegakan hukum jaminan sosial tenaga kerja sering tidak dilaksanakan sesuai dengan ketentuan yang berlaku. Dalam hal pengenaan sanksi administratif yang berupa pencabutan ijin usaha, setelah diketahui ada pelanggaran biasanya Departemen Tenaga Kerja hanya memberikan peringatan saja kepada perusahaan yang bersangkuran. Peringatan itu diberikan dua kali dalam waktu tiga bulan, maksudnya peringatan kedua diberikan jika sudah terhitung tiga bulan dari peringatan pertama.

Sejauh itu belum pernah dilaksanakan pengenaan sanksi administratif berupa pencabutan ijin usaha, kecuali peringatan-peringatan sebagai bentuk konkret dari berstuurdwang. Mungkin sudah ada perusahaan yang dijatuhi sanksi baik pidana maupun administratif kami belum mengadakan surve lebih mendalam, sudah ada berapa perusahaan atau Yayasan yang sudah pernah atau sedah dijatuhi sanksi baik sanksi administratif maupun pidana. Ada beberapa hal yang perlu diperhatikan mungkin belum dijatuhkannya sanksi pencabutan ijin usaha karena pencabutan ijin usaha dapat mengakibatkan penutupan perusahaan yang tentunya mengakibatkan pemutusan hubungan kerja, yang merugikan karyawan. Akibat karyawan akan kehilangan penghasilan yang biasa diterimanya dan dibutuhkan untuk memenuhi kebutuhan keluarganya. Pengenaan denda administaratif terhadap perusahaan oleh BPJS dapat juga karena keterlambatan pembayaran iuran. Biasanya terdapat penyimpangan-penyimpangan dalam hal ini yaitu apabila denda yang harus dibayarkan oleh pengusaha terlalu banyak, maka pengusaha berupaya memohon keringanan. Dengan cara mempengaruhi petugas BPJS agar mengubah data keterlambatan tersebut. kalau hal ini terjadi tentunya akan sangat merugikan badan penyelenggara karena terjadi pengurangan pendapatan. Pengenaan uang paksa oleh pemerintah dalam hal ini Departenem Tenaga Kerja kepada badan penyelenggara BPJS jika terjadi keterlambatan pembayaran kepada tenaga kerja. Biasanya tidak pernah terjadi karena badan penyelenggara selalu tepat waktu melakukan pembayaran kepada pekerja.

\section{Pelaksanaan Pemberian Jaminan Sosial Melalui BPJS Di Yayasan Perguruan 17 Agustus 1945 Surabaya}

Bahwa Yayasaan merupakan Badan Hukum yang mempunyai pengurus dan karyawan yang tentunya sama dengan badan hukum yang lainnya seperti Perseroan Terbatas maupun Koperasi adalah wajib menjadi peserta BPJS bagi karyawan maupun pengurusnya. Yayasan Perguruan 17 Agustus 1945 Surabaya atau YPTA adalah Badan Hukum Penyelenggara Universitas 17 Agustus 1945 (Untag) Surabaya, Politeknik 17 Agustus 1945 Surabaya, Sekolah Menengah Atas (SMA) 17 Agustus 1945 Surabaya dan Sekolah Menengah Pertama (SMP) 17 Agustus 1945 Surabaya. Menurut bagian Ketenagaan Untag pada saat ini jumlah karyawan 552 karyawan, yang terdiri dari tenaga dosen dan tenaga kependidikan dan berkedudukan hukum di Jl. Semolowaru 45 Surabaya. Bergerak dibidang Pendidikan serta didirikan berdasarkan Akta Notaris R. Julihan Reksohadi, Nomor 29 Tahun 1957 beserta Akta Perubahannya. Tenaga Edukasi (dosen dan guru) tetap yayasan dan tenaga administrasi tetap Yayasan Perguruan 17 Agustus 1945 Surabaya. Tenaga dosen untuk Universitas dan Politeknik 17 Agustus 1945 Surabaya dan guru SMA dan SMP 17 Agustus 1945 Surabaya. Untuk dosen jenjang pendidikan minimal strata dua (S-2) atau magister. Sedangkan untuk guru paling rendah jenjang berpendidikannya adalah strata satu 
DiH Jurnal Ilmu Hukum

Volume 14 Nomor 27

Februari 2018

Jemikan

(S-1). Sedangkan untuk tenaga administasi perkantoran minimal berpendidikan Sekolah Menengah Atas.

Keikutsertaan karyawan Yayasan Perguruan 17 Agustus 1945 Surabaya dalam BPJS dapat memberikan sarana aman dan juga menambah ketenangan bagi setiap karyawan. BPJS sebagai badan penyelenggara memberikan perlindungan terhadap berbagai resiko yang berlangsung pada karyawan akibat terputusnya penghasilaan, karena tertimpa kecelakaan kerja, sakit akibat kerja, hari tua dan meninggal dunia. Dalam hal ini Yayasan dipandang perlu melaporkan adanya jumlah karyawan yang bekerja dan memberitahukan upahnya secara benar kepada BPJS sebagai penyelenggara jaminan sosial, dengan demikian akan terwujud apa arti dan manfaat yang diharapkan dalam program BPJS tersebut. Sedangkan yang menjadi sumber perhitungan yaitu atas upah karyawan menurut PP Nomor 44-46 Tahun 2015, dikatakan bahwa:

Upah adalah hak pekerja yang diterima yang dinyatakan dalam bentuk uang sebagai imbalan dari pemberi kerja kepada pekerja yang ditetapkan dan dibayar menurut suatu perjanjian kerja, kesepakatan atau peraturan perundang undangan, termasuk tunjangan bagi pekerja dan keluarganya atas suatu pekerjaan dan/atau jasa yang telah atau akan dilakukan. ${ }^{9}$

Berdasarkan pasal di atas maka pengertian upah adalah termasuk dalam bentuk suatu komponen satuan yang tidak bisa dipisah-pisahkan dengan pemberian tunjangan yang lain, sehinga unsur-unsur tersebut dapat dipakai sebagai dasar perhitungan besarnya upah yang harus dibayarkan oleh Yayasan sebagai pembiayaan atau iuran dalam keikutsertaannya dalam program BPJS. Adapun pelaporan upah yang benar akan mengakibatkan perhitungan yang mudah, namun sebaliknya apabila tidak benar juga menyulitkan petugas baik Yayasan maupun Badan penyelenggara Jaminan Sosial dalam menentukan jumlah uang Jaminannya.

Dalam menghadapi perusahaan yang mendaftarkan sebagaian upah karyawan nya petugas BPJS tidak berwenang untuk melakukan pengecekan langsung pada perusahaan yang bersangkutan karena BPJS dalam memperhitungkan hanyalah berdasarkan laporan dari seksi pengawas ketenaga kerjaan Disnaker setempat. Setelah menerima laporan tentang daftar mengenai gaji dari Yayasan/perusahaan, maka kepala seksi pengawas Ketenaga kerjaan Disnaker mengadakan pengecekan secara langsung, apakah sudah sesuai dengan ketentuan Upah Minimum Kabupataen/Kota. Yayasan Perguruan 17 Agustus 1945 Surabaya, dalam hal mengantisipasi adanya kecelakaan kerja telah mengupayakan peningkatkan keselamatan dan kesehatan kerja terhaadap para karyawannya, hal ini terbukti telah tersedianya sarana-sarana dan fasilitas yang diberikan diantaranya:

1. Yayasan telah menyediakan Poliklinik sendiri sejak tahun 1980 yang dilengkapi dengan 5 orang tenaga dokter umum dan dokter gigi serta 3 orang tenaga medis.

2. Yayasan Perguruan 17 Agustus 1945 Surabaya, melalui Rektor telah mengadakan kerja sama dengan PMI Pusat, untuk mengadakan penyediaan bank darah.

3. Yayasan juga menyediakan sarana alat pencegah atau pemadam kebakaran secara automatis sesuai dengan fungsinya.

${ }_{9}^{9}$ Depkum Ham, RI, 2015. 
BPJS dalam melaksanakan fungsinya memberikan jaminan kecelakaan kerja, sakit dan cacat akibat kerja, sesuai Peraturan Pemerintah Nomor 44 tahun 2015 akan diberikan kepada yang bersangkutan sesuai dengan kompensasi JKK, yaitu transport, biaya pengobatan dan STMB. Kalau terjadi kecelakaan kerja pihak perusahaan, keluarga atau kawan sekerja membawa langsung ke Trauma Center terdekat, untuk mengurangi biaya yang akan dikeluarkan oleh pihak perusahaan. Pada saat ini pegawai yayasan yang mengalami kecelakan ditempat kerja dikatagorikan nihil, yang ada kecelkaan kerja yang berhubungan dengan berlalu lintas di jalan raya. Masalah penggantian biaya kecelakaan kerja dapat dijadikan sebagai dasar untuk menuntut ganti rugi kepada BPJS Ketenagakerjaan sebagaimana telah diatur dengan Peraturan Pemerintah Nomor 44 Tahun 2015 yaitu mengenai jaminan kecelakaan kerja yang menimpa karyawan yang terbatas dalam hubungan kerja bukan di luar hubungan kerja. Sampai saat ini karyawan Yayasan Perguruan 17 Agustus 1945 Surabaya, sangat jarang terjadi kecelakaan kerja yang bisa dikatagorikan tersebut di atas. Siapa yang ingin mendapatkan musibah, tentunya secara akal sehat tidak ada, sekalipun ada jaminan dilandasi oleh:

a. Sikap berhati-hati, setiap karyawan dalam melakukan suartu pekerjaan.

b. Selalu mentaati tata tertib berlalu lintas dijalan raya, pada waktu berangkat kerja dan pada waktu pulang kerja.

c. Hal lain karyawan selama melakukan pekerjaan di kantor tidak bersentuhan secara langsung dengan mesin-mesin, sebagai penyebab tinggi risiko kecelakaan kerja. Disamping telah diatur oleh Peraturan Pemerintah Nomor 84 Tahun 2013, mengenai penggantian biaya kecelakaan kerja, BPJS Ketanagakerjaan membentuk Unit Trauma Center (TC) untuk menangani jika ada tenaga kerja menalami kecelakaan kerja, sehingga tenaga kerja harus terdaftar di fasilitas trauma setempat.

Di dalam hal karyawan meninggal dunia, maka ahli waris yang bersangkutan mengajukan surat permintaan pembayaran santunan Jaminan Kematian yang dibuat dalam formulir BPJS 4 , yaitu permintaan pembayaran Jaminan kematian dan dikirimkan ke kantor Jamsostek setempat, yang di lampiri antara lain:

a. Surat keterangan dari dokter Rumah Sakit dimana karyawan tersebut dirawat,

b. Surat keterangan kematian dari lurah setempat,

c. Kartu Peserta Jaminan Hari Tua/ JHT (asli).

d. KTP asli dan Foto Copy KSK,

e. Foto Copy surat Nikah.

Kemudian BPJS membayar jumlah uang jaminan kematian, biaya pemakaman dan Jaminan Hari Tua sekaligus kepada ahli waris karyawan. Karyawan yang menjadi peserta BPJS tersebut telah meninggal dunia dan meninggalnya bukan merupakan akibat kecelakaan kerja atau belum mencapai usia setara pensiun 58 tahun, maka ahli waris karyawan tersebut akan menerima jaminan kematian dari BPJS. Hal ini sesuai dengan Peraturan Pemerintah Nomor 44 Tahun 2015, dijelaskan bahwa:

1. Jamianan Kematian dibayar sekaligus kepada janda atau duda, atau anak-anaknya yang jumlahnya sebagai berikut:

a. Santunan kematian sebesar Rp. 16.200.000.-

b. Biaya pemakaman sebesar Rp. 3.000.000.-

c. Santunan berkala sebesar Rp. 200.000.- x 24 bulan Rp. 4.800.000.- 
DiH Jurnal Ilmu Hukum

Volume 14 Nomor 27

Februari 2018

Jemikan

d. jumlahnya sekitar Rp. 24.000.000.- + beasiswa;

e. Bantuan Beasiswa bagi anak peserta yang masih kuliah Rp. 12.000.000.-

Santunan kematian ini tidak termasuk uang Jaminan Hari Tua (JHT), jadi hak-hak karyawan apabila meninggal sebelum usia 58 tahun akan diberikan semuanya kepada ahli warisnya.

b. Dalam hal janda atau duda atau anak tidak ada, maka jaminan kematian dibayar kepada keturunan sedarah yang ada pada karyawan, menurut garis lurus ke bawah dan garis lurus ke atas dan dihitung sampai derajat kedua.

c. Dalam hal tenaga kerja tidak mempunyai keturunan sedarah sebagaimana dimaksud pada ayat (2), maka jaminan kematian dibayar sekaligus kepada pihak yang ditunjuk oleh tenaga kerja dalam wasiatnya.

Jaminan hari sesuai Peraturan Pemerintah No. 46 Tahun 2015 dapat diambil setelah mencapai usia 56 tahun atau mengalami cacat total atau pindah ke luar atau dikeluarkan oleh perusahaan, maka BPJS memberitahukan jumlah hari tua yang sesuai formulir permintaan pembayaran Jaminan Hari tua. Kemudian bagi karyawan mengajukan Surat Permintaan tunjangan jaminan hari tua ke kantor BPJS terdekat dengan mengisi formulir BPJS, yang harus diisi oleh perusahaan yang disertai dengan bukti-bukti KTP, KSK, surat Nikah, Kartu BPJS. Selanjutnya BPJS menetapkan dan membayar sejumlah uang tunjangan jaminan hari tua kepada karyawan dengan di buatkan kwitansi tanda terima pembayaran oleh pihak penyelenggara jaminan hari tua.

Pengajuan pembayaran jaminan hari tua (JHT) dapat dilakukan:

1. Jika karyawan tersebut telah mencapai usia 58 tahun;

2. Jika karyawan tersebut meninggal dunia sebelum usia 58 tahun;

3. Jika karyawan tersebut diberhentikan;

4. Jika karyawan tersebut mengundurkan diri dari Yayasan tempat dia bekerja.

Persaratannya untuk mengajukan pembayaran adalah :

1. dengan menunjukkan Surat Keputusan (SK) dari yayasan tentang pemberhentiannya;

2. membawa kartu peserta BPJS Ketenagakerjaan (KPJ) asli;

3. Kartu Tanda Penduduk;

4. Kartu susunan keluarga.

Sedangkan jumlah yang akan didapat dari BPJS Ketenagakerjaan disesuaikan dengan premi yang dibayarkan dan pengembangannya selama waktu tertentu. Yayasan menanggung semua biaya yang harus dibayarkan kepada pihak penyelenggara yaitu Jamsostek. Karena kemampuannya terbatas yang dibayarkan kepada Jamsostek mengenai JHT saat ini disesuaikan dengan upah minimum (UMK). Sedangkan kekurangannya jaminan hari tua selama ini di tanggung oleh Yayasan. Karena sesuai dengan Pasal 167 ayat (2) Undangundang ketenagakerjaan bahwa dalam hal besarnya Jaminan Hari Tua ternyata lebih kecil dari ketentuan Pasal 156 ayat (2, 3 dan 4), maka selisih atau kekurangannya dibayar oleh Yayasan.

\section{Penutup}

Berdasarkan dengan pembahasan yang telah dilakukan dapat disimpulkan sebagai berikut:

a. Pemberian perlindungan terhadap tenaga kerja dan Penegakan Hukum terhadap pelaksanaan BPJS sebagai penyelenggara dirasa masih kurang memadai, terutama 
masalah masih rendahnya jaminan yang diberikan terhadap tenaga kerja. Mengenai program yang ada tentunya sudah baik akan tetapi perlu ada peningkatan pengawasan terhadap upah yang diberikan oleh yayasan.

b. Sesuai Undang-undang BPJS setiap Pemberi Kerja dan Pekerjanya wajib didaftarkan menjadi peserta, hal ini di samping untuk menjamin kelangsungan hidup karyawan juga untuk menjamin kepastian hukumnya.

Saran yang dapat diberikan terhadap masalah ini sebagai berikut:

a. Karena aspek-aspek perlindungan jaminan sosial tenaga kerja di Indonesia sudah diatur dengan Undang-undang BPJS, maka dalam hal ini dapat ditingkatkan mengingat tenaga kerja, Swasta di Indonesia kesejahteraannya kurang memadai, untuk itu akan menambah semangat kerja jika BPJS memberikan peluang sarana dari dana yang masuk untuk didayagunakan, membuat peluang untuk menambah modal UKM dan Kredit Kepemilikan Rumah atau tanah bagi peserta.

b. Ada kemudahan dalam pengambilan hak jaminan bagi karyawan, mengingat jaminan ini semata-mata untuk tenaga kerja berdasarkan atas hak dan kewajibannya. Pemerintah hendaknya selalu meningkatkan pengawasan mengenai penegakan hukum dibidang ketenagakerjaan.

\section{Daftar Pustaka}

Abdul Gani, Penegakan Hukum Beberapa Masalahnya, Diskusi Mengenai Penegakan Hukum Di Lingkungan Kota Madya Tingkat II Surabaya, Fakultas Hukum Universitas Airlangga, Saurabaya 1981.

Fajar, Ali Mukti, Masalah penegakan Hukum, Masalah Arena Hukum. VII (2) Jember, 1979.

Soepomo, Imam, Hukum Perburuhan, Djembatan, Jakarta, 1992.

- Hukum Perburuhan Bidang Kesehatan Kerja Perlindungan Buruh, Pradnya Paramita, Jakarta, 1992.

Marmosujono, Sukarton, Penegakan Hukum Di Negara Pancasila, Pustaka Kartini, Jakarta, 1989

Pangaribuhan Simanjuntak, Emmy, Hukum Pertanggungan, Seksi Hukum Dagang, Fakultas Hukum UGM, Yogyakarta, 1980.

Soebekti, R dan Tjitrosudibio, R, Kitab Undang-Undang Hukum Dagang Dan Undang-Undang Kepalitan, Pradnya Paramita, Jakarta, 1993.

Soekanto, Soerdjono, Faktor-Faktor Yang Mempengaruhi Penegakan Hukum, Raja Grafindo, Persada, Jakarta, 2013.

Wignjosoebroto, Soetandyo, Faktor-Faktor Yang Mempengaruhi Ke Efektifan Hukum Yang Melaksanakan Fungsinya Sebagai Sarana Kontrol Sosial, Terjemahan C.G. Howart dan Mumner, law: Its nature and Limets, New Jersey, Pretice, Hall. 1993. 